\title{
Lymphoma Cell Count
}

National Cancer Institute

\section{Source}

National Cancer Institute. Lymphoma Cell Count. NCI Thesaurus. Code C74613.

The determination of the number of lymphoma cells present in a sample. 